\title{
Analysis of Bacillus subtilis 168 prophage-associated lytic enzymes; identification and characterization of CWLA-related prophage proteins
}

\author{
SIMON J. FOSTER* \\ Department of Molecular Biology and Biotechnology, University of Sheffeld, PO Box 594, Firth Court, \\ Western Bank, Sheffield S10 2UH, UK
}

(Received 26 April 1993; revised 28 June 1993; accepted 4 August 1993)

\begin{abstract}
The CWLA lytic amidase of Bacillus subtilis 168 was purified and antisera raised against the purified protein. No expression of $c w l A$ could be demonstrated under any conditions by the use of the antisera and $c w l A:: l a c Z$ fusion analysis. Two lytic enzymes of apparent molecular masses 34 and $30 \mathrm{kDa}$ (as measured by renaturing SDSPAGE) were found to be mitomycin $\mathrm{C}$-inducible, the larger of which corresponds to a protein immunologically related to CWLA. Both of these inducible lysins were found to be encoded by prophage PBSX. Prophage SP $\beta$ was shown by renaturing SDS-PAGE to produce a 43 kDa lytic enzyme unrelated immunologically to CWLA. The smaller of the two PBSX enzymes was purified and found to be an $N$-acetylmuramyl-L-alanine amidase of $32 \mathrm{kDa}$ (as measured by SDS-PAGE and Coomassie blue staining) which cross-reacts only weakly with the anti-CWLA sera. The potential origin of $c w l A$ and its possible relationship to the other phage lytic enzymes are discussed.
\end{abstract}

\section{Introduction}

Autolysins are apparently ubiquitous bacterial enzymes capable of hydrolysing cell wall peptidoglycan (Ghuysen et al., 1966). Many species contain multiple autolysins but their role during growth and division has yet to be established. Bacillus subtilis 168 has two major vegetative cell autolysins, a $90 \mathrm{kDa}$ glucosaminidase and a $50 \mathrm{kDa}$ amidase (Herbold \& Glaser, 1975; Rogers et al., 1984). The structural genes for these enzymes have been isolated recently, sequenced and inactivated (Kuroda \& Sekiguchi, 1991; Lazarevic et al., 1992; Margot, 1992; Margot \& Karamata, 1992). The mutant inactivated in the gene encoding the $50 \mathrm{kDa}$ amidase was more resistant to lysis during stationary phase than the parent strain. Two other autolysins of 34 and $30 \mathrm{kDa}$ have been identified during vegetative growth by the use of renaturing SDS-PAGE; however, their hydrolytic bond specificity is unknown (Foster, 1991). During differentiation, three novel enzymes appear, one of which may be responsible for mother-cell lysis at the end of sporulation.

A further $B$. subtilis lytic enzyme has been identified by a direct screening technique from expression libraries of B. subtilis genomic DNA (Kuroda \& Sekiguchi, 1990; Foster, 1991). The cloned gene encodes a $30 \mathrm{kDa}$ amidase which in Escherichia coli is processed to a $21 \mathrm{kDa}$ form

*Author for correspondence. Tel. +44742824411 ; fax +44742 728697 .
(Foster, 1991; Kuroda et al., 1991). A mutant inactivated in the structural gene for this enzyme ( $c w l A)$ showed the same phenotype as the parent and the inactivation of cwlA cannot be correlated with the loss of any of the known autolysins during vegetative growth or differentiation (Foster, 1992).

$B$. subtilis generally contains two prophages, $\mathrm{SP} \beta$ and PBSX, which can be induced during growth by mitomycin $\mathrm{C}$ treatment resulting in cell lysis by the action of phage lytic enzymes (Mauel \& Karamata, 1984; Hemphill, 1990). Two PBSX lytic enzymes have been identified previously as an amidase of $14.5 \mathrm{kDa}$ and a muramidase of undetermined size (Ward et al., 1982). However CWLA cannot be encoded by SP $\beta$ or PBSX as it maps in a different part of the B. subtilis chromosome (Piggot, 1989; Foster, 1991).

This paper describes work to try to establish the identity and expression conditions of the CWLA lytic enzyme to elucidate its role during growth and relationship to the other lytic enzymes of $B$. subtilis 168 . As part of this study the lytic enzymes of SP $\beta$ and PBSX have been characterized by renaturing SDS-PAGE and a PBSX amidase has been purified.

\section{Methods}

Bacterial strains and growth conditions. All strains of Bacillus subtilis 168 used in this study are shown in Table 1. Growth was carried out at $37{ }^{\circ} \mathrm{C}$ in nutrient broth (NB, Oxoid) with shaking ( 250 r.p.m.) unless otherwise stated. Growth media for strains 1 A60 and RB1144 were 
Table 1. B. subtilis 168 strains

\begin{tabular}{|c|c|c|}
\hline Strain & Genotype & Source/Reference* \\
\hline HR & $\operatorname{trp} C 2$ & Laboratory stock \\
\hline SF2 & $\operatorname{trp} C 2 \mathrm{cwlA}$ & $\begin{array}{l}\text { Laboratory stock } \\
\text { (Foster, 1992) }\end{array}$ \\
\hline SF3 & $\operatorname{trpC} 2 \mathrm{cwlA}:: \mathrm{pSFP} 10 \mathrm{cwlA} A^{+}$ & This study \\
\hline $1 \mathrm{~A} 60$ & metC3 pyr $A$ xin- 1 & $\begin{array}{l}\text { BGSC (Thurm \& } \\
\text { Garro, 1975) }\end{array}$ \\
\hline RB1144 & $\begin{array}{l}\text { pyrD ilvAl thy } A \text { thy } B \Delta(P B S X-p r o- \\
\text { metC })\end{array}$ & $\begin{array}{l}\text { P. Longchamp } \\
\text { (Buxton, 1980) }\end{array}$ \\
\hline L4587 & metC ile xhi-1479 & $\begin{array}{l}\text { P. Longchamp } \\
\text { (P. Jaunin, } \\
\text { unpublished data) }\end{array}$ \\
\hline $1 \mathrm{~A} 372$ & $S P \beta c 2$ novAl recF15 trpC2 xin & BGSC \\
\hline $1 \mathrm{~A} 692$ & metB5 sp $\beta^{s}$ & BGSC \\
\hline CU2059 & $\begin{array}{l}{[\text { metB5] da1-1 }(S P \beta c 2)(S P \beta c 2 \text { int } 5} \\
\text { dsup44-1) }\end{array}$ & $\begin{array}{l}\text { A. Moir (Lipsky } \\
\text { et al., 1981) }\end{array}$ \\
\hline
\end{tabular}

*BGSC, Bacillus Genetic Stock Centre, Department of Biochemistry, Ohio State University, Columbus, OH, USA.

supplemented with uracil and thymine (each $50 \mu \mathrm{g} \mathrm{ml}^{-1}$ ), respectively. Escherichia coli DH5 $\alpha$ was grown in Luria-Bertani medium (LB) containing ampicillin $\left(50 \mu \mathrm{g} \mathrm{ml}^{-1}\right)$ at $37^{\circ} \mathrm{C}$ with shaking (250 r.p.m.) where appropriate.

Assay for lytic enzyme activity. B. subtilis vegetative cell wall substrate was purified as described previously (Foster, 1991) and used in the spectrophotometric assay for lytic enzyme activity (Foster, 1991). Each assay was carried out in duplicate. One unit of enzyme activity is defined as the amount of enzyme necessary to decrease the $\mathrm{OD}_{450}$ of a wall suspension by $0.001 \mathrm{~min}^{-1}$ at $37^{\circ} \mathrm{C}$.

Purification of the recombinant CWLA protein and preparation of antisera. A CWLA-containing extract $(50 \mathrm{ml})$ of $E$. coli $\mathrm{DH} 5 \alpha$ with plasmid pSFP102 was prepared as described previously (Foster, 1991) from 51 of culture. The extract was centifuged $\left(100000 \mathrm{~g}, 1 \mathrm{~h}, 4^{\circ} \mathrm{C}\right)$ to remove insoluble material and the supernatant dialysed overnight against 51 of $10 \mathrm{~mm}$-Tris/ $\mathrm{HCl}, \mathrm{pH} 7.5$ at $4{ }^{\circ} \mathrm{C}$. After dialysis a white precipitate had formed which contained $>95 \%$ of the enzyme activity. This precipitate was collected by centrifugation $\left(10000 \mathrm{~g}, 5 \mathrm{~min}, 4^{\circ} \mathrm{C}\right)$ and washed three times in dialysis buffer by resuspension and centrifugation. The final pellet was then resuspended in $50 \mathrm{ml}$ of $300-$ $\mathrm{mm} \mathrm{KCl}, 50 \mathrm{~mm}$-Tris/ $\mathrm{HCl}, \mathrm{pH} 7.5$ (resuspension buffer) by gentle mixing at $4{ }^{\circ} \mathrm{C}$ overnight. After centrifugation $\left(20000 \mathrm{~g}, 20 \mathrm{~min}, 4^{\circ} \mathrm{C}\right)$ to remove insoluble material, the enzyme-containing solution was loaded on a $10 \times 1.6 \mathrm{~cm}$ column containing Reactive Red 120-Agarose (Sigma) equilibrated with enzyme resuspension buffer. All the enzyme bound to the column and was eluted with a linear gradient of $\mathrm{LiCl}$ $(0-3 \mathrm{M})$ in enzyme resuspension buffer. The enzyme-containing fractions were pooled and the enzyme precipitated by dialysis against two changes of 100 vols of $10 \mathrm{~mm}-\mathrm{Tris} / \mathrm{HCl}, \mathrm{pH} 7.5$ at $4{ }^{\circ} \mathrm{C}$. After dialysis the precipitated enzyme was recovered and resuspended as above. After SDS-PAGE (Laemmli, 1970), the $21 \mathrm{kDa}$ protein corresponding to the processed major recombinant form of CWLA was electroeluted (Extraphor, LKB), extensively dialysed against water and the resulting precipitate recovered. The preparation was resuspended in water and used for the production of anti-CWLA sera in a rabbit. For the initial injections, $100 \mu \mathrm{g}$ of purified protein was used and $50 \mu \mathrm{g}$ per boost.

Construction of a $B$. subtilis strain carrying a cwlA::lac $Z$ fusion. Plasmid pSFP100 carries a $3 \mathrm{~kb} E c o \mathrm{R} 1$ insert containing the $c w l A$ gene and surrounding sequences (Foster, 1991). A 936 bp HindIII fragment was excised from this plasmid, end-filled and purified (Geneclean, Stratech Scientific). This fragment contains the coding sequence for the first 108 amino acids of CWLA and 672 bp of upstream sequence (Foster, 1991). After ligation into Smal-cut and dephosphorylated pAZ106 (Kemp et al., 1991; A. Zuberi \& R. Doi, unpublished data) this construct was used to transform E. coli DH5 (Hanahan, 1983). The orientation of the fragment in pAZ106, which created a transcriptional fusion between $c w l A$ and $l a c Z$, was confirmed by restriction mapping and the construct pSFP10 used to transform competent B. subtilis $168 \mathrm{HR}$ (Anagnostopoulos \& Spizizen, 1961). Recombinants were selected by plating on erythromycin $\left(1 \mu \mathrm{g} \mathrm{ml}^{-1}\right)$ and lincomycin $\left(25 \mu \mathrm{g} \mathrm{ml}^{-1}\right)$ containing nutrient agar plates. The insertion resulting in the $c w l A:: l a c Z$ fusion was checked by Southern blotting (Sambrook et al., 1989) using the 936 bp HindIII fragment as probe. $\beta$-Galactosidase activity was measured by the method of Youngman (1990) using 4-methylumbelliferyl- $\beta$-D-galactopyranoside (MUG) as the substrate.

Renaturing SDS-PAGE and Western blotting. SDS extracts of cultures were prepared for SDS-PAGE as described previously (Foster, 1992). Renaturing SDS-PAGE and visualization of lytic enzyme activity was exactly as described previously (Foster, 1992). Samples for Western blot analysis were separated by $11 \%$ SDS-PAGE, transferred to nitrocellulose and treated with the anti-CWLA sera by the method of Burnette (1981). Antigen--antibody complexes were detected by the use of goat anti-rabbit IgG coupled to alkaline phosphatase (Sigma). All experiments were repeated at least twice and the results show representative examples.

Mitomycin $C$ and prophage mutant induction. Mitomycin $\mathrm{C}$ induction was performed by the addition of mitomycin $\mathrm{C}$ (Sigma) to a final concentration of $0.5 \mu \mathrm{g} \mathrm{ml}^{-1}$ (Buxton, 1980) to a growing culture at $37^{\circ} \mathrm{C}$ in nutrient broth. SP $\beta$ was induced in the strain CU2059 by the addition of $1 / 3$ volume of boiling NB to an exponentially growing culture at $37^{\circ} \mathrm{C}$ (Rosenthal et al., 1979). The culture was held at $50^{\circ} \mathrm{C}$ for $6 \mathrm{~min}$ and then returned to incubate at $37^{\circ} \mathrm{C}$ to allow the phage to replicate. PBSX was induced in the strain $\mathrm{L} 4587$ by the transfer of an exponentially growing culture at $37^{\circ} \mathrm{C}$ to a shaking water bath at $45^{\circ} \mathrm{C}$ to allow phage replication and cell lysis.

Purification and characterization of a PBSX lysin. Following temperature induction of a $500 \mathrm{ml}$ culture of L4587 which carries the xin mutation (Buxton, 1976), lysis was allowed to proceed for $3 \mathrm{~h}$. Debris was then removed by centrifugation $\left(15000 \mathrm{~g}, 20^{\circ} \mathrm{C}, 10 \mathrm{~min}\right.$; step 1). The supernatant containing the enzyme activity was concentrated by $85 \%(\mathrm{w} / \mathrm{v})$ ammonium sulphate precipitation $\left(30 \mathrm{~min}, 20^{\circ} \mathrm{C}\right.$, with stirring) and centrifugation $\left(10000 \mathrm{~g}, 20^{\circ} \mathrm{C}, 10 \mathrm{~min}\right)$. The pellet was resuspended in $5 \mathrm{ml}$ of $100 \mathrm{mM}-\mathrm{NaCl}, 1 \mathrm{~mm}-\mathrm{PMSF}$ and $20 \mathrm{~mm}-$ Tris $/ \mathrm{HCl}, \mathrm{pH} 7 \cdot 5$, and dialysed against two changes of 200 vols of the resuspension buffer without PMSF at $4{ }^{\circ} \mathrm{C}$. The extract was then centrifuged $\left(20000 \mathrm{~g}, 10 \mathrm{~min}, 4^{\circ} \mathrm{C}\right)$ to remove insoluble material (step 2). The supernatant was applied to a $5 \mathrm{ml}$ Econo-Pac Q cartridge anion exchange column (Bio-Rad) equilibrated in the dialysis buffer. The enzyme activity did not bind to the column and passed through (step 3). The enzyme solution was concentrated in dialysis tubing by solid polyethylene glycol (Sigma) extraction before dialysis as above against 100 vols of buffer. This concentrated enzyme preparation $(3.5 \mathrm{ml})$ was applied to a $1.6 \times 100 \mathrm{~cm}$ Sephadex G75 Superfine column equilibrated in dialysis buffer and eluted at $0.15 \mathrm{ml} \mathrm{min}^{-1}$ with the same buffer. Fractions containing enzyme ( $18 \mathrm{ml}$ total; step 4$)$ were pooled and dialysed against two changes of 100 vols of $20 \mathrm{~mm}-\mathrm{Tris} / \mathrm{HCl}, \mathrm{pH} 7 \cdot 5$, at $4{ }^{\circ} \mathrm{C}$. After filtration $(0.45 \mu \mathrm{m}$ pore size $)$ the enzyme solution was applied to the Econo-Pac $Q$ cartridge anion exchange column equilibrated in dialysis buffer. All enzyme activity bound to the column. The enzyme was eluted with a linear gradient of $0-100 \mathrm{~mm}$ $\mathrm{NaCl}$ in dialysis buffer at $1 \mathrm{ml} \mathrm{min}^{-1}$ over $100 \mathrm{~min}$. The enzymecontaining fractions were pooled $(14 \mathrm{ml}$ total; step 5$)$ and a sample concentrated by trichloroacetic acid precipitation for purity analysis by SDS-PAGE. 
The mode of action of the enzyme was determined exactly as described previously (Foster, 1991). Purified $32 \mathrm{kDa}$ lytic enzyme was dialysed against 100 vols of $10 \mathrm{~mm}$-potassium phosphate buffer, $\mathrm{pH} 7 \cdot 0$. Purified walls were digested at $2 \mathrm{mg} \mathrm{ml}^{-1}$ in $20 \mathrm{mM}^{-\mathrm{MgSO}_{4}, 10 \mathrm{~mm}-}$ potassium phosphate buffer, $\mathrm{pH} 7.0$ at $37^{\circ} \mathrm{C}$ containing $960 \mathrm{U} \mathrm{ml}^{-1}$ of purified enzyme. Periodically $0.5 \mathrm{ml}$ samples were removed for $\mathrm{OD}_{450}$ readings and determination of the appearance of new reducing and amino termini. The method of Margot et al. (1991) as described by Foster (1991) was used to determine to which isomer of alanine new amino termini could be attributed.

The $\mathrm{N}$-terminal sequence of the purified $32 \mathrm{kDa}$ amidase was determined using an Applied Biosystems 476A Protein sequencer.

\section{Results}

Production and use of anti-CWLA sera to identify $C W L A$-related proteins during growth and differentiation

The recombinant CWLA protein was purified from an $E$. coli strain carrying the plasmid pSFP102 as described in Methods by selective precipitation and reactive red 120 dye affinity chromatography. The enzyme was eluted at about $1 \mathrm{M}-\mathrm{LiCl}$ from the reactive red column. The activity-containing eluate was analysed by $11 \%$ SDSPAGE and the $21 \mathrm{kDa}$ CWLA protein electroeluted. Antiserum was raised in rabbits to this recombinant protein and used to probe various cell extracts by Western blotting (Fig. 1a). The antiserum reacts with two proteins of 30 and $21 \mathrm{kDa}$ in an extract of $E$. coli(pSFP102) (Fig. 1 $a$, track 2) which match the sizes of the active precursor and processed forms of CWLA in $E$.

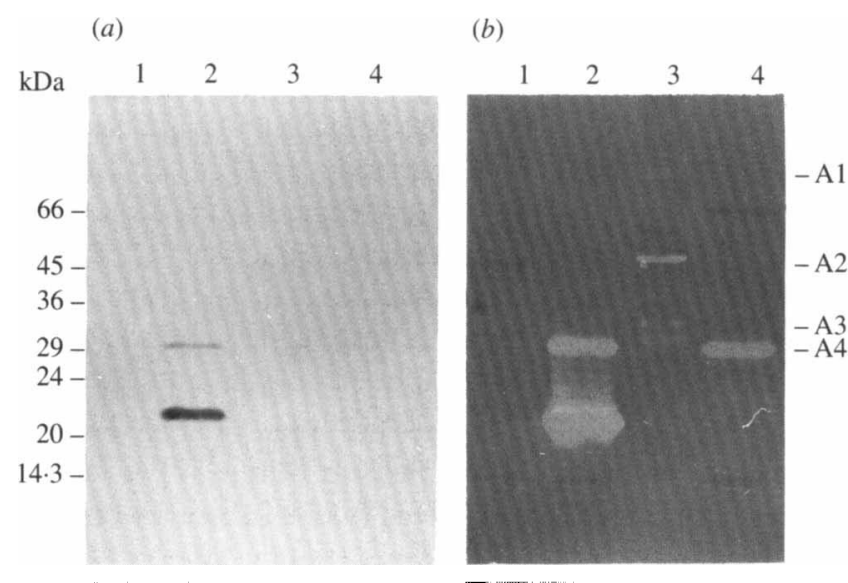

Fig. 1. Use of anti-CWLA antisera to identify CWLA-related proteins during vegetative growth and differentiation. Samples were prepared as described previously (Foster, 1991, 1992) and separated by $11 \%$ SDSPAGE. All samples contained $10 \mu \mathrm{g}$ protein. (a) Western blot probed with anti-CWLA sera and visualized as described in Methods; $(b)$ renaturing gel containing $0.05 \%(\mathrm{w} / \mathrm{v})$ purified $B$. subtilis 168 vegetative cell walls as the substrate. Tracks: $1, E$. coli DH5 $\alpha$ (pUBS1) extract; 2 , E. coli $\mathrm{DH} 5 \alpha(\mathrm{pSFP} 102)$ extract; $3, B$. subtilis $168 \mathrm{HR}$ vegetative cell SDS extract (Foster, 1992); 4, SDS extract of sporulating cell culture of B. subtilis $168 \mathrm{HR} 8 \mathrm{~h}$ after induction (Foster, 1992). The molecular masses of standards separated on the same gel are indicated as is the identity of the major lytic bands (Foster, 1992). coli (Fig. $1 b$, track 2). The specificity of the sera is shown by the inability of an $E$. coli(pUBS) extract (plasmid without $c w l A$-containing insert), which has no autolytic activity against $B$. subtilis walls (Fig. $1 b$, track 1 ), to cross-react with the sera (Fig. $1 a$, track 1). CWLA is not related to any proteins in an SDS extract of vegetative or stage VI sporulating cells which show the characteristic autolysin profiles (Fig. $1 a, b$, tracks $3 \& 4$ ). Either CWLA or related proteins are not present in these samples or are at too low a level to be detected using the antisera.

\section{Analysis of cwlA expression by the creation of a cwlA::lacZ fusion}

Plasmid pSFP10 contains a 936 bp HindIII, end-filled fragment from pSFP100 ligated into pAZ106. Transformation of this plasmid into $B$. subtilis $\mathrm{HR}$ resulted in the creation of strain SF3 containing a cwlA::lacZ fusion. Analysis of the expression of the reporter gene $\beta$ galactosidase revealed no increase in expression as compared to $B$. subtilis HR background levels either during vegetative growth or differentiation (results not shown). The $c w l A:: l a c Z$ transcriptional fusion was expressed in E. coli $\mathrm{DH} 5 \alpha$ because colonies of a clone harbouring plasmid pSFP10 were blue on LB ampicillin plates which had been spread with $80 \mu \mathrm{l}$ of a $20 \mathrm{mg} \mathrm{ml}^{-1}$ solution of X-gal in dimethylformamide.

\section{Identification of mitomycin C-inducible lytic enzymes and their antigenic relationship to CWLA}

Mitomycin $\mathrm{C}$ exposure is commonly used for the induction of prophage in $B$. subtilis 168 . Treatment of an exponentially growing culture of strain $\mathrm{HR}\left(\mathrm{OD}_{600}=0 \cdot 2\right)$ resulted in the cessation of growth as measured by the increase in $\mathrm{OD}_{600}(0 \cdot 72)$ after about $1 \mathrm{~h}$, followed by cellular lysis (Fig. $2 a$ ). A renaturing gel of SDS extracts of samples taken during mitomycin $\mathrm{C}$ treatment is shown in Fig. 2(b). After $60 \mathrm{~min}$, a large increase appears in the amounts of the A3 and A4 lytic bands of molecular masses approximately 34 and $30 \mathrm{kDa}$, respectively (Fig. $2 b$, track 4). These further increase during the time of cellular lysis. Neither of these bands corresponds to the product of the $c w l A$ gene, as strain SF2, which is inactivated in $c w l A$, still shows the same mitomycin Cinduced lytic profile (Fig. $2 b$, track 8). Also, no expression of the $c w l A$ gene occurs during mitomycin $\mathrm{C}$ treatment as measured by the $c w l A:: l a c Z$ fusion created above. Interestingly, however, if these SDS extract samples were analysed by Western blotting using the anti-CWLA sera as the probe, a mitomycin C-induced CWLA-cross-reactive protein appeared concomitant with the increase in lytic activity (Fig. $2 c$ ). This protein 


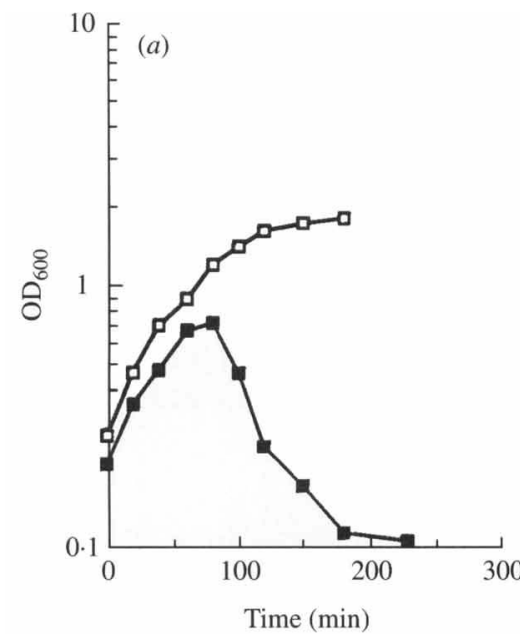

(b)

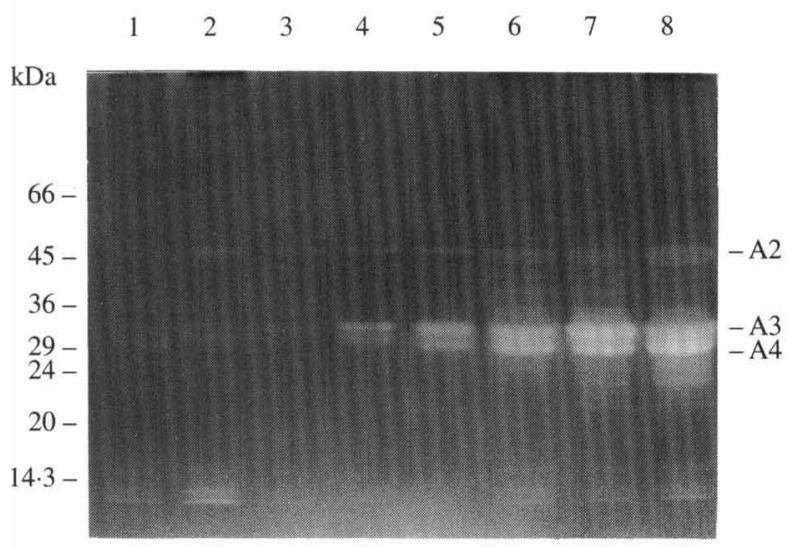

(c)

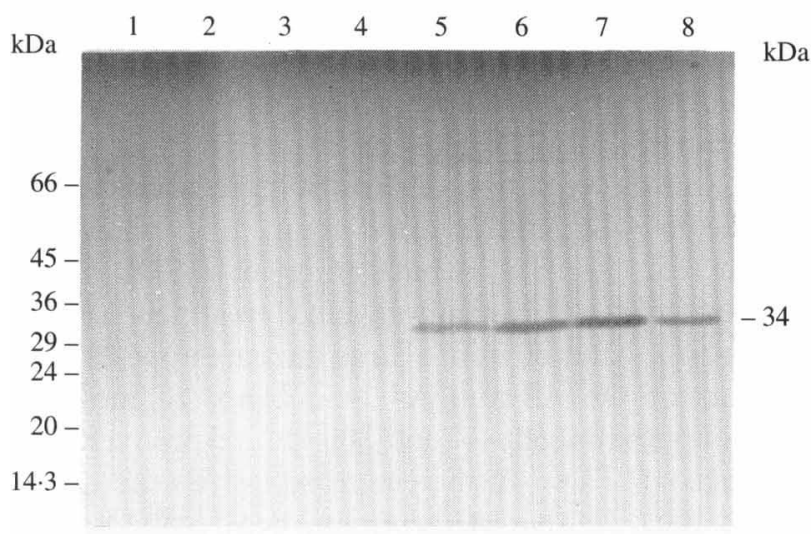

Fig. 2. Identification of mitomycin C-induced lytic enzymes and a CWLA-related protein. (a) The effect of mitomycin C $\left(0.5 \mu \mathrm{g} \mathrm{ml}{ }^{-1}\right)$ on growth $\left(\mathrm{OD}_{600}\right)$ of $B$. subtilis $168 \mathrm{HR}$ was measured $(\boldsymbol{\square})$ as compared to an untreated control culture $(\square)$. The results are from a representative experiment from which the samples were taken for further analysis. Samples were taken at various times after addition of mitomycin $\mathrm{C}$ to both an $\mathrm{HR}$ and an SF2 (cwlA-inactivated) culture. SDS-extracts were prepared as described previously (Foster, 1992) and separated by $11 \%$ SDS-PAGE. All samples contained $10 \mu \mathrm{g}$ protein. (b) Renaturing SDS-PAGE. (c) Western blot probed with anti-CWLA sera. Tracks: $1-7$, SDS extracts of $B$. subtilis 168 HR taken at $0,20,40$, $60,80,100$ and $120 \mathrm{~min}$, respectively, after the addition of mitomycin has a molecular mass of $34 \mathrm{kDa}$ which corresponds to the $34 \mathrm{kDa}$ mitomycin C-induced lytic enzyme. It is not CWLA itself as the $c w l A$-inactivated mutant still shows this protein (Fig. $2 c$, track 8 ).

\section{Identification of B. subtilis 168 prophage lytic enzymes}

B. subtilis generally contains two mitomycin C-inducible prophages, PBSX and SP $\beta$. To determine if the mitomycin C-induced lytic enzymes were prophage-encoded, the lytic profiles of various phage mutants were examined.

Strain CU2059 bears the SP $\beta \mathrm{C} 2$ mutation which confers $\mathrm{SP} \beta$ temperature-sensitive induction. Fig. 3(a) shows the optical density of a culture grown at $37^{\circ} \mathrm{C}$ until $\mathrm{OD}_{600}=0.33$ and then heat-shocked at $50^{\circ} \mathrm{C}$ for $6 \mathrm{~min}$ before continued incubation at $37^{\circ} \mathrm{C}$. About 20 min after heat shock the culture stopped growing and began to lyse. Concurrent with this lysis was the induction of a $43 \mathrm{kDa} \mathrm{SP} \beta$-specific lytic enzyme as shown by renaturing SDS-PAGE (Fig. $3 b$ ). This $43 \mathrm{kDa}$ enzyme did not cross-react with the anti-CWLA sera as shown by Western blotting (data not shown). No lytic enzyme induction occurred upon heat shock of strain $\mathrm{HR}$ and mitomycin C-induction of a strain cured of SP $\beta$ (1A692) showed an identical pattern of lytic enzyme induction to strain HR.

Strain L4587 carries the xhi-1479 mutation which allows specific heat shock-induction of PBSX (P. Jaunin, University of Lausanne, Switzerland, unpublished data). Conversely RB1144 has had the PBSX prophage deleted (Buxton, 1980). The optical density of a mitomycin Ctreated culture of RB1144 and a heat-shocked L4587 is shown in Fig. 4(a). The PBSX-deleted strain was no longer mitomycin $\mathrm{C}$-sensitive and carried on growing (Fig. $4 a$ ) although at a reduced rate compared with a non-treated control (results not shown). The PBSX temperature-sensitive strain stops growing after about $60 \mathrm{~min}$ at $45^{\circ} \mathrm{C}$ and then begins to lyse. Renaturing SDS-PAGE revealed the induction concomitant with lysis, of the two lytic enzymes A3 and A4 (Fig. $4 b$ ) the larger of which corresponded to the CWLA crossreactive protein (Fig. $4 \mathrm{c}$ ). Thus, both of these mitomycin $\mathrm{C}$-induced lysins are PBSX-associated. Mitomycin C treatment of the PBSX-deleted strain (RB1144) showed no increase in the two lytic enzymes or induction of the CWLA cross-reactive protein (Fig. $4 b, c$ ). Strains $1 \mathrm{~A} 372$ and $1 \mathrm{~A} 60$ which have the xin mutation, such that PBSX cannot be induced, are mitomycin C-resistant and

C; 8, SDS-extract of B. subtilis $168 \mathrm{SF} 2120 \mathrm{~min}$ after the addition of mitomycin $\mathrm{C}$. The position of molecular mass standards and the major lytic bands are indicated. 


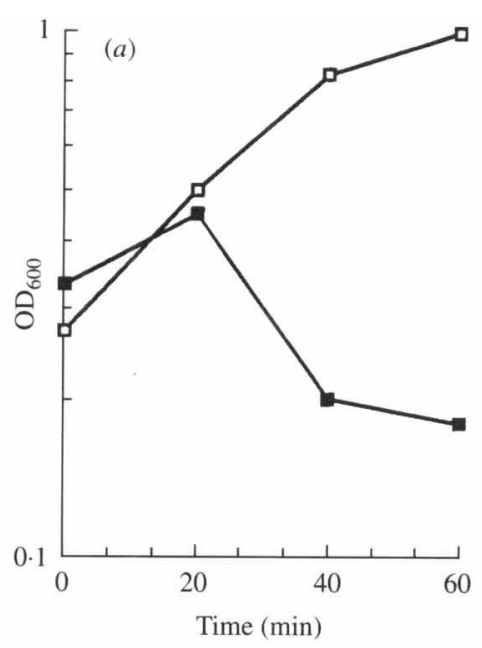

(b)

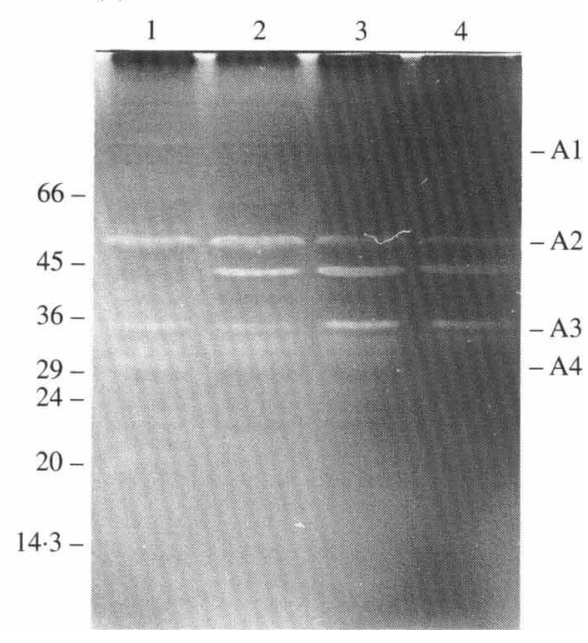

Fig. 3. Identification of an SP $\beta$-associated lytic enzyme. Prophage SP $\beta$ was heat-induced in strain CU2059 as described in Methods and samples taken every $20 \mathrm{~min}$ for analysis. (a) $\boldsymbol{\square}, \mathrm{OD}_{600}$ of CU2059 after heat induction; $\square$, uninduced control. The results are from a representative experiment from which samples were taken for further analysis. (b) Renaturing SDS-PAGE analysis of SDS extracts $(10 \mu \mathrm{g}$ protein) of heat-induced CU2059. Samples were taken at 0, 20, 40 and 60 min after induction (tracks $1-4$, respectively). The sizes of the major lytic bands and molecular mass standards are indicated.

no lytic enzyme or CWLA-related proteins are induced in response to mitomycin $\mathrm{C}$ (data not shown).

\section{Purification of a PBSX-encoded lytic enzyme}

PBSX has been shown to produce two lytic enzymes, a $14.5 \mathrm{kDa}$ amidase (as measured by gel filtration) and a muramidase of unknown size (Ward et al., 1982). To determine if the PBSX lytic enzymes shown in this study correspond to the previously identified enzymes, purification of the proteins from a lysate of the temperaturesensitive strain L4587 was attempted. Only one lytic

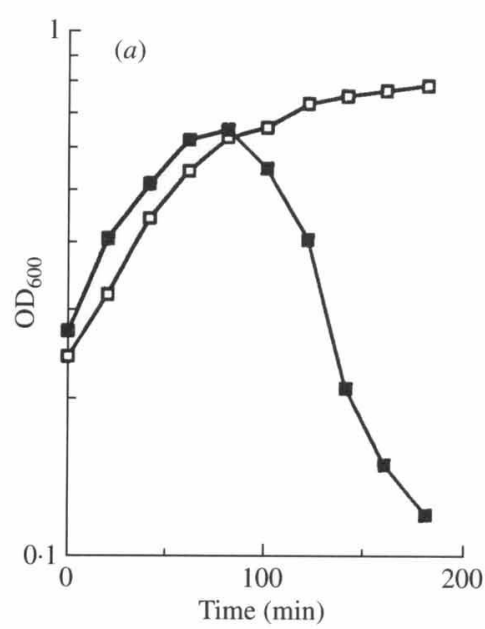

(b)

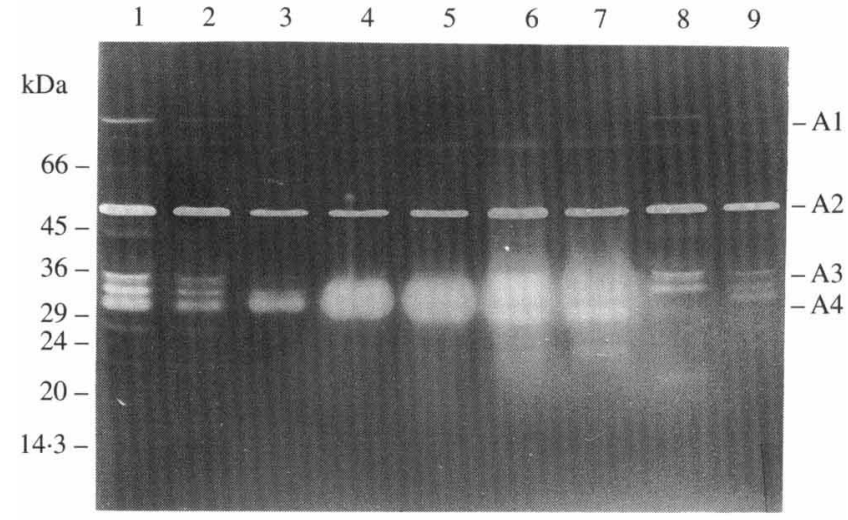

(c)

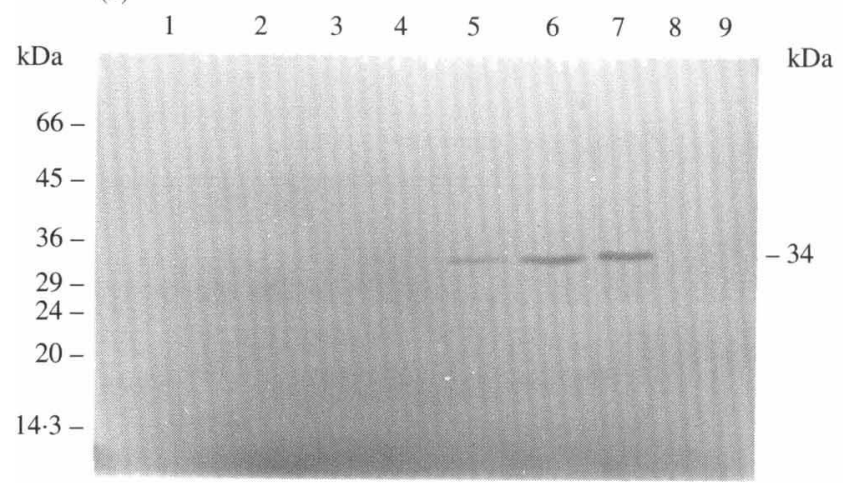

Fig. 4. Identification of PBSX-associated lytic enzymes. PBSX was heat-induced in strain L4587 and strain RB1144 was mitomycin Ctreated as described in Methods. (a) $\mathrm{OD}_{600}$ of the two cultures; L4587; $\square$, RB1144. The results are from a representative experiment from which samples were taken for further analysis. (b) Renaturing SDS-PAGE analysis of SDS extracts from the treated cultures. (c) Western blot probed with anti-CWLA sera. Tracks: 1-7, strain L4587, $0,20,40,60,80,100$ and $120 \mathrm{~min}$, respectively, after transfer to $45^{\circ} \mathrm{C}$; 8 and 9, strain RB1144, 0 and 120 min, respectively, after the addition of mitomycin C. All the samples contained $10 \mu \mathrm{g}$ protein. The sizes of the major lytic bands and molecular mass standards are indicated.

activity could be purified from the lysate (Fig. $5 a$; Table 2 ). The amount of lytic activity of this enzyme in the 


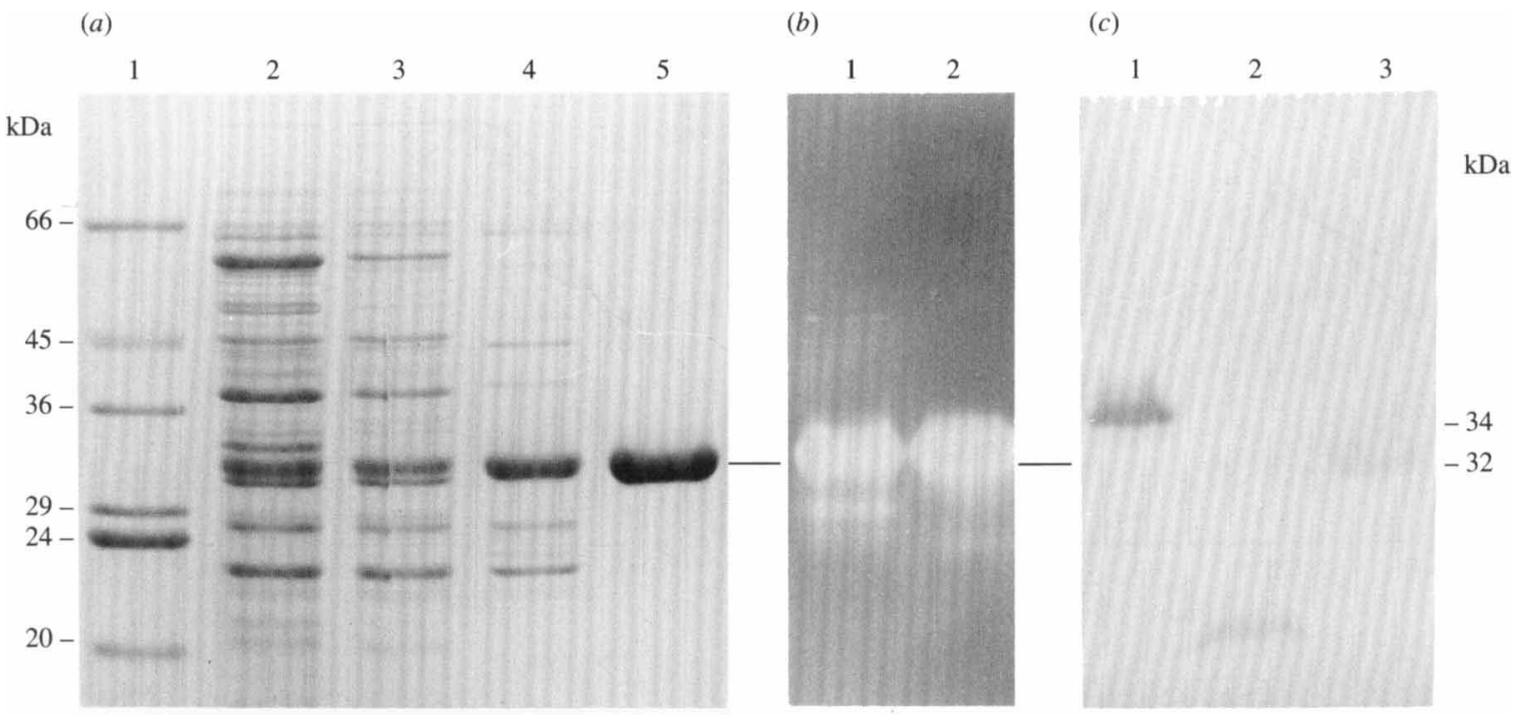

Fig. 5. Purification of a PBSX-associated lytic enzyme. For details of the various samples, see Table 2 and Methods. (a) Coomassie blue-stained SDS-PAGE gel of samples taken during the purification procedure. All samples contained $10 \mu \mathrm{g}$ protein. Track 1, molecular mass standards of sizes indicated; 2, ammonium sulphate precipitate; 3, Econo-Pac Q unbound material; 4, Sephadex G75 eluate; 5, Econo-Pac Q eluate (purified enzyme). (b) Renaturing SDS-PAGE. Track, 1, ammonium sulphate precipitate (5 $\mu \mathrm{g}$ protein); 2, Econo-Pac Q eluate ( $5 \mu \mathrm{g}$ purified protein). (c) Western blot probed with anti-CWLA sera. All samples contained $5 \mu \mathrm{g}$ protein. Track 1, SDS-extract of HR 120 min after mitomycin C treatment (see Fig. 2c, track 7); 2, ammonium sulphate precipitate; 3, Econo-Pac $\mathrm{Q}$ eluate (purified protein). The sizes of molecular mass standards are indicated.

Table 2. Purification of the $32 \mathrm{kDa} P B S X$-associated lytic enzyme

\begin{tabular}{lccrcc}
\hline \hline \multicolumn{1}{c}{ Purification step } & $\begin{array}{c}\text { Volume } \\
(\mathrm{ml})\end{array}$ & $\begin{array}{c}\text { Activity } \\
\left(\mathrm{U} \mathrm{ml}^{-1}\right)\end{array}$ & $\begin{array}{r}\text { Specific } \\
\text { activity } \\
\left(\mathrm{U} \mathrm{mg}^{-1}\right)\end{array}$ & $\begin{array}{c}\text { Yield } \\
(\%)\end{array}$ & $\begin{array}{c}\text { Purification } \\
(\text {-fold })\end{array}$ \\
\hline 1. Cell lysate & 460 & 70 & 1400 & 100 & 1 \\
2. Ammonium sulphate precipitate & 11 & 3250 & 1800 & 111 & $1 \cdot 3$ \\
3. Econo-Pac Q wash-through & 17 & 2530 & 2400 & 133 & $1 \cdot 7$ \\
4. Sephadex G75 Superfine eluate & 18 & 2440 & 11100 & 136 & $7 \cdot 8$ \\
5. Econo-Pac Q eluate & 14 & 1260 & 12000 & 52 & $8 \cdot 5$ \\
\hline \hline
\end{tabular}

lysate could not be accounted for by vegetative cell activity. Table 2 shows the results from one representative purification of the lytic enzyme which was repeated three times. The increase in apparent yield seen after some steps during the purification procedure may be due to the removal of an endogenous inhibitor or the activation of a latent proform (Table 2). No fractions containing lytic enzyme activity were found at any point during the procedure apart from those associated with the enzyme which was purified. The enzyme was purified and found to have a molecular mass of $32 \mathrm{kDa}$ as measured by Coomassie blue staining after SDS-PAGE, and $30 \mathrm{kDa}$ by renaturing SDS-PAGE (Fig. $5 a, b$ ). SDSPAGE and Western blotting revealed that protein redissolved after ammonium sulphate precipitation of the lysate contained different CWLA-related proteins than the SDS extract from the lysing cells (Fig. $5 c$, tracks 1 and 2). Instead of the $34 \mathrm{kDa}$ band, the lysate contained a cross-reactive $18 \mathrm{kDa}$ band. The $18 \mathrm{kDa}$ antiseracross-reactive band had no lytic activity as measured by renaturing SDS-PAGE (Fig. $5 b$, track 1). The purified $32 \mathrm{kDa}$ enzyme also reacted weakly with the antisera (Fig. $5 c$, track 3).

Determination of the hydrolytic bond specificity of the purified $32 \mathrm{kDa}$ lytic enzyme

A suspension of purified B. subtilis 168 vegetative cell walls $\left(5 \mathrm{mg} \mathrm{ml}^{-1}\right)$ was hydrolysed by the purified $32 \mathrm{kDa}$ PBSX autolysin (results not shown). After $60 \mathrm{~min}$, more than $75 \%$ of the initial $\mathrm{OD}_{450}$ of the wall suspension had been lost. Concomitant with this decrease in $\mathrm{OD}_{450}$ was a large increase in the number of free amino termini [430 $\left.\mathrm{nmol}(\mathrm{mg} \text { cell wall })^{-1}\right]$. After $60 \mathrm{~min}$ digestion with the purified enzyme there was no increase in the number of wall-reducing termini. Acid hydrolysis of the FDNB 
labelled samples followed by TLC analysis identified only an increase in $N$-2,3-dinitrophenyl-DL-alanine (DNP-alanine) on hydrolysis of the walls with purified lysin. The use of $\mathrm{L}-\left[{ }^{14} \mathrm{C}\right]$ alanine-labelled walls (Margot et al., 1991) identified this DNP-alanine increase to be solely accounted for by DNP-L-alanine and thus the enzyme is an $\mathrm{N}$-acetylmuramyl-L-alanine amidase (amidase).

\section{$N$-terminal sequencing of the $32 k D a P B S X$ amidase}

The $\mathrm{N}$-terminal sequence of the purified $32 \mathrm{kDa}$ amidase protein was determined to elucidate its relationship to other known lytic enzymes. The 16 amino acid sequence MVNIIQDFIPVGANRP determined did not match CWLA or any other sequences in the database. This sequence does, however, match exactly that of the cloned and sequenced major amidase of PBSX (P. Longchamp, P. Jaunin \& D. Karamata, unpublished data).

\section{Discussion}

The gene encoding the CWLA amidase has been cloned and inactivated but the function and expression pattern of this enzyme has remained elusive (Kuroda \& Sekiguchi, 1990; Foster, 1991). The antiserum raised to the purified CWLA protein in this study is specific in its reaction to the 30 and $21 \mathrm{kDa}$ recombinant forms of CWLA and no other E. coli proteins. As far as can be ascertained, $c w l A$ is never expressed in $B$. subtilis even under mitomycin $C$ treatment in which a CWLA-related protein appears. This protein of $34 \mathrm{kDa}$ is larger than CWLA $(30 \mathrm{kDa})$ and is present in a strain inactivated in the $c w l A$ gene. To gain a further insight into the identity of this CWLA-related protein, the resident prophageassociated lytic enzymes of $B$. subtilis 168 were characterized.

Three prophage-encoded lytic enzymes of $B$. subtilis 168 were identified during this work. The prophage SP $\beta$ encodes a $43 \mathrm{kDa}$ enzyme of unknown hydrolytic bond specificity. This enzyme is not present during vegetative growth, differentiation or mitomycin $\mathrm{C}$ prophage induction in measurable amounts as judged by renaturing SDS-PAGE. This is not surprising as although $\mathrm{SP} \beta$ is spontaneously induced at a low level during vegetative growth and this induction is greatly increased upon mitomycin $\mathrm{C}$ treatment, the titre is still far less than one infectious particle per bacterium (Warner et al., 1977). Mitomycin $\mathrm{C}$ treatment induces two lytic enzymes of apparent molecular masses 34 and $30 \mathrm{kDa}$ as judged by renaturing SDS-PAGE. Both of these enzymes were found to be PBSX-associated. Only one enzyme could be purified from a lysate of a PBSX temperature-sensitive strain. This was the smaller of the two PBSX enzymes in
SDS extracts and the purified protein has a molecular mass of $32 \mathrm{kDa}$ as measured by SDS-PAGE and Coomassie blue staining but $30 \mathrm{kDa}$ by renaturing SDSPAGE. A PBSX amidase was partially purified by Ward et al. (1982) and found to have a molecular mass of $14.5 \mathrm{kDa}$ as measured by gel filtration. SDS-PAGE, however, showed the preparation to contain two proteins of 30 and $14.5 \mathrm{kDa}$ (Ward et al., 1982). The amidase purified in this study may correspond to the $30 \mathrm{kDa}$ component of the previously partially purified amidase. The major CWLA cross-reactive lytic enzyme of $34 \mathrm{kDa}$ may be the unpurified PBSX muramidase of Ward et al. (1982).

Interestingly, although it is not apparent in SDS extracts of lysing cells, the $32 \mathrm{kDa}$ PBSX amidase does cross-react to a low level with the CWLA antisera as can be seen using the purified protein. In fact the $32 \mathrm{kDa}$ PBSX amidase and CWLA show 50\% amino acid sequence identity (P. Longchamp, P. Jaunin \& D. Karamata, unpublished data). The $34 \mathrm{kDa}$ major CWLA cross-reactive band, which is probably the mitomycin Cinducible $34 \mathrm{kDa}$ lytic enzyme, was not recovered from the PBSX-containing lysate after temperature induction of strain L4587. Instead of the $34 \mathrm{kDa}$ cross-reactive band there was an $18 \mathrm{kDa}$ protein which reacted with the antisera. Thus it seems likely that the $34 \mathrm{kDa}$ protein is quite unstable and subject to proteolysis, even after PMSF treatment, and was lost during purification. The PBSX late operon encodes two proteins of 31.5 and $32.5 \mathrm{kDa}$ which are comparable in size to the lytic enzymes identified in this study (Mauel \& Karamata, 1984; Wood et al., 1990).

From the results it can be seen that CWLA is related immunologically to two lytic enzymes of the defective prophage PBSX. PBSX produces defective non-infectious particles as it is unable to package its own DNA. PBSX-like defective prophages are found in many Bacilli and cured strains have not been isolated. Thus it seems that the maintenance of these phages is in some way advantageous for the cell (Buxton, 1980). It is possible that CWLA is also phage-encoded on another redundant copy of PBSX or a closely related phage. The map locations are such that $c w l A$ cannot be encoded for by PBSX itself and may therefore be on a cryptic prophage which can no longer be induced even by the action of mitomycin $\mathrm{C}$ and thus $\mathrm{cwlA}$ is never expressed. The $c w l A$ gene seems to be expressed from its own promoter in E. coli and so is in itself functional (Foster, 1991). A regulatory mutation analogous to the xin mutation of PBSX (Thurm \& Garro, 1975) may be responsible for the lack of expression of $c w l A$. The four open reading frames flanking the $c w l A$ gene show no significant homology to any protein sequences in the databases (Foster, 1991); however, further sequencing of the PBSX 
genome may well identify a homologous region to that containing $c w l A$.

A further lysin structural gene has been isolated by the direct screening method used to clone $c w l A$ and the recombinant protein shows low level cross-reactivity with the anti-CWLA sera (Foster, 1991; Greene \& Foster, unpublished data). The map location and specificity of this enzyme are at present unknown. This new lytic enzyme may also be of prophage origin.

To understand the individual and cooperative roles of the lytic enzymes of $B$. subtilis one must first identify the complement of enzymes present. PBSX produces two lytic enzymes of between 30 and $34 \mathrm{kDa}$. By the use of renaturing SDS-PAGE it seems there is at least one other enzyme present in this size range in vegetative cells of $B$. subtilis 168 (Foster, 1992). The creation of isogenic multiple and single lytic enzyme inactivated mutants to try to understand the function of lytic enzymes must take into account the presence of spontaneously induced prophage enzymes.

This work was carried out during the tenure of the $\mathbf{J}$. G. Graves Medical Research Fellowship and a Royal Society University Research Fellowship. I am very grateful to Pascal Longchamp and Anne Moir for provision of strains and also Dimitri Karamata and Pascal Longchamp for sharing results before publication.

\section{References}

Anagnostopoulos, C. \& SpIzizen, J. (1961). Requirements for transformation in Bacillus subtilis. Journal of Bacteriology 81, 741-746.

BuRNETTE, W. M. (1981). Western blotting: electrophoretic transfer of proteins from sodium dodecyl sulfate-polyacrylamide gels to unmodified nitrocellulose and radiographic detection with antibody and radioiodinated protein-A. Analytical Biochemistry 112, 195-203.

Buxton, R. S. (1976). Prophage mutation causing heat inducibility of defective Bacillus subtilis bacteriophage PBSX. Journal of Virology 20, 22-28.

BuxTon, R. S. (1980). Selection of Bacillus subtilis 168 mutants with deletions of the PBSX prophage. Journal of General Virology 46, 427-437.

Foster, S. J. (1991). Cloning, expression, sequence analysis and biochemical characterization of an autolytic amidase of $B$. subtilis 168 trpC2. Journal of General Microbiology 137, 1987-1998.

FosTer, S. J. (1992). Analysis of the autolysins of Bacillus subtilis 168 during vegetative growth and differentiation by using renaturing gel electrophoresis. Journal of Bacteriology 174, 464-470.

Ghuysen, J.-M., Tipper, D. J. \& Strominger, J. L. (1966). Enzymes that degrade bacterial cell walls. Methods in Enzymology 8, 685-699.

Hanahan, D. (1983). Studies on transformation of Escherichia coli with plasmids. Journal of Molecular Biology 166, 557-580.

HempHILl, H. E. (1990). Bacteriophages. In Molecular Biological Methods for Bacillus, pp. 451-491. Edited by C. R. Harwood \& S. M. Cutting. Chichester: Wiley \& Sons.

HERBOLD, D. R. \& GLASER, L. (1975). Bacillus subtilis $N$-acetylmuramic acid L-alanine amidase. Journal of Biological Chemistry 250, 1676-1682.

Kemp, E. H., Sammons, R. L., Moir, A., Sun, D. \& Setlow, P. (1991).
Analysis of transcriptional control of the ger $D$ spore germination gene of Bacillus subtilis 168. Journal of Bacteriology 173, 4646-4652.

Kuroda, A. \& SeKiguchi, J. (1990). Cloning, sequencing and genetic mapping of a Bacillus subtilis cell wall hydrolase gene. Journal of General Microbiology 136, 2209-2216.

KurODA, A. \& SeKIGUCHI, J. (1991). Molecular cloning and sequencing of a major Bacillus subtilis autolysin gene. Journal of Bacteriology 173, 7304-7312.

Kuroda, A., Imazeki, M. \& Sekiguchi, J. (1991). Purification and characterization of a cell wall hydrolase encoded by the $c w l A$ gene of Bacillus subtilis. FEMS Microbiology Letters 81, 9-14.

LAEMmLI, U. K. (1970). Cleavage of structural proteins during the assembly of the head of bacteriophage T4. Nature, London 227, 680-685.

Lazarevic, V., Margot, P., Soldo, B. \& Karamata, D. (1992). Sequencing and analysis of the Bacillus subtilis lyt $R A B C$ divergon: a regulatory unit encompassing the structural genes of the $N$-acetyl muramoyl-L-alanine amidase and its modifier. Journal of General Microbiology 138, 1949-1961.

Lipsky, R. H., Rosenthal, R. \& Zahler, S. A. (1981). Defective specialized $\operatorname{SP} \beta$ transducing bacteriophages of Bacillus subtilis that carry the sup-3 or sup-44 gene. Journal of Bacteriology 148, 1012-1015.

Margot, P. (1992). Genetique des autolysines de Bacillus subtilis. PhD thesis, University of Lausanne, Switzerland.

Margot, P. \& Karamata, D. (1992). Identification of the structural genes for $\mathrm{N}$-acetylmuramoyl-L-alanine amidase and its modifier in Bacillus subtilis 168: inactivation of these genes by insertional mutagenesis has no effect on growth or cell separation. Molecular and General Genetics 232, 359-366.

Margot, P., Roten, C.-A. H. \& Karamata, D. (1991). Nacetylmuramoyl-L-alanine amidase assay based on specific radioactive labelling of muropeptide L-alanine: quantification of the enzyme activity in the autolysin deficient Bacillus subtilis 168, faD strain. Analytical Biochemistry 198, 15-18.

Mauel, C. \& Karamata, D. (1984). Characterization of proteins induced by mitomycin C treatment of Bacillus subtilis. Journal of Virology 49, 806-812.

PIGGOT, P. J. (1989). Revised genetic map of Bacillus subtilis 168. In Regulation of Procaryotic Development, pp. 1-41. Edited by I. Smith, R. A. Slepecky \& P. Setlow. Washington, DC: American Society for Microbiology.

Rogers, H. J., Taylor, C., Rayter, S. \& Ward, J. B. (1984). Purification and properties of an autolytic endo- $\beta$-glucosaminidase and the $N$-acetylmuramyl-L-alanine amidase from Bacillus subtilis strain 168. Journal of General Microbiology 130, 2395-2402.

Rosenthal, R., Toye, P. A., Korman, R. Z. \& Zahler, S. A. (1979). The prophage of $\mathrm{SP} \beta c 2 \mathrm{~d} c i t K_{1}$, a defective specialized transducing phage of Bacillus subtilis. Genetics 92, 721-739.

SambrooK, J., Fritsch, E. F. \& Maniatis, T. (1989). Molecular Cloning: A Laboratory Manual. Cold Spring Harbor, NY: Cold Spring Harbor Laboratory.

ThURM, P. \& GARRo, A. J. (1975). Isolation and characterization of prophage mutants of the defective Bacillus subtilis bacteriophage PBSX. Journal of Virology 16, 184-191.

Ward, J. B., Curtis, C. A. M., TAylor, C. \& Buxton, R. S. (1982). Purification and characterization of two phage PBSX-induced lytic enzymes of Bacillus subtilis 168: an $N$-acetylmuramoyl-L-alanine amidase and an $\mathrm{N}$-acetylmuramidase. Journal of General Microbiology 128, 1171-1178.

Warner, F. D., Kitos, G. A., Romano, M. P. \& Hemphill, H. E. (1977). Characterization of SP $\beta$ : a temperate bacteriophage from Bacillus subtilis 168M. Canadian Journal of Microbiology 23, 45-51.

Wood, H. E., Dawson, M. T., Devine, K. M. \& McConnell, D. J. (1990). Characterization of PBSX, a defective prophage of Bacillus subtilis. Journal of Bacteriology 172, 2667-2674.

YounGMAN, P. (1990). Use of transposons and integrational vectors for mutagenesis and construction of gene fusions in Bacillus species. In Molecular Biological Methods for Bacillus, pp. 221-266. Edited by C. R. Harwood \& S. M. Cutting. Chichester: Wiley \& Sons. 